\title{
Persepsi Mahasiswa Terhadap Pembelajaran Daring di Prodi Pendidikan Seni Pertunjukan FKIP Untan Pontianak
}

\author{
Nurmila Sari Djau, Asfar Munir, Imam Ghozali. \\ Prodi Pendidikan Seni Pertunjukan, Untan \\ nurmilasari.djau@fkip.untan.ac.id
}

\begin{abstract}
Received: 13 August 2021; Revised: 02 October 2021; Accepted: 28 December
2021 DOI: http://dx.doi.org/10.37905/aksara.8.1.513-524.2022
\end{abstract}

\begin{abstract}
Abstrak
Tujuan penelitian ini adalah (1) Untuk mengetahui bagaimana persepsi Mahasiswa terhadap pembelajaran daring di Prodi Pendidikan Seni Pertunjukan FKIP Untan Pontianak (2) Untuk mengetahui faktor-faktor pendukung maupun penghambat terlaksananya pembelajaran daring. Jenis penelitian merupakan Deskriptif, dengan pendekatan kualitatif. Pengumpulan data berupa wawancara, observasi dan dokumentasi. Sumber data peneliti berasal dari informan, observasi, dokumen yang berkaitan dengan pembelajaran daring. Adapun analisis data meliputi, reduksi, penyajian, penarikan kesimpulan. Hasil penelitian ini adalah bahwa hampir keseluruhan mahasiswa baik Pendidikan Seni Musik maupun Tari berpendapat bahwa mata kuliah praktek sebaiknya dilaksanakan secara tatap muka dengan alasan mahasiswa masih bergantung pada peralatan penunjang perkuliahan yang ada di kampus. Dengan pembelajaran tatap muka mata kuliah praktik lebih mudah dipahami terutama pada teknik memainkan alat musik bagi mahasiswa musik dan juga teknik gerak bagi mahasiswa tari. Sedangkan mata kuliah teori mahasiswa memilih daring. Namun tidak dipungkiri ada mata kuliah tertentu bersifat teori, menurut mahasiswa lebih baik dilaksanakan secara tatap muka, contohnya: Teori Musik, Harmoni, notasi tari, hal ini disebabkan mata kuliah tersebut membutuhkan pemahaman yang lebih dalam. Implikasi dari penelitian ini diharapkan dapat memberikan informasi pelaksanaan mata kuliah secara daring maupun tatap muka berdasarkan persepsi mahasiswa dengan menerapkan protokol kesehatan yang ketat.
\end{abstract}

Kata Kunci: Persepsi Mahasiswa, Pembelajaran Daring

\section{PENDAHULUAN}

Pembelajaran daring merupakan proses pembelajaran yang dilaksanakan pada masa Pandemi Covid 19. Pada awalnya dikeluarkannya perintah untuk melaksnakan pembelajaran daring, menimbulkan reaksi masyarakat yang pro dan kontra. Namun walaupun demikian pembelajaran daring tetap dilaksanakan, dengan alasan demi memutus rantai penyebaran virus dan menjaga keamanan serta keselamatan peserta didik dan tenaga pendidik.Dengan adanya himbauan tersebut maka proses pembelajaran dilakukan jarak jauh yaitu dari rumah dengan memanfaatkan teknologi dan media internet yang ada.

Keputusan pemerntah ini dituliskan dalam surat keputusan bersama 4 Menteri Nomor 01/KB/2020 tanggal 15 juni 2020 tentang Panduan Penyelenggaraan Pembelajaran pada Tahun Ajaran 2020/2021 dan Tahun Akademik 2020/2021 di Masa Pandemi Corona Virus Disease (Covid-19). Keputusan ini bukan hanya berlaku untuk mata kuliah yang bersiat teoritis namun juga berlaku bagi mata kuliah vokasi/ praktik bila memungkinkan diselenggarakan secara daring atau waktunya ditunda di bagian akhir semester atau semester berikutnya dengan tetap memenuhi protokol kesehatan dan keselamatanpeserta. 
Adanya himbauan tersebut, maka proses pembelajaran di Prodi Pendidikan Seni Pertunjukan FKIP Untan juga ikut menerapkan proses pembelajaran secara daring. Pembelajaran secara daring dianggap menjadi solusi terbaik terhadap kegiatan belajar mengajar di tengah pandemi Covid-19 demi berlangsungnya suatu proses pembelajaran. Pada awal pembelajaran daring di Prodi Seni menimbulkan masalah baru bagi mahasiswa dan dosen. Masalah tersebut berupa terkendala akses jaringan dalam pembelajaran, kurang optimalnya aktivitas belajar mahasiswa saat pembelajaran berlangsung, keterbatasan media pembeajaran khususnya untuk mata kuliah pratik. Permasalahan ini dapat dikemukaan oleh penulis berdasarkan pengalaman mengajar saat pembelajaran daring berlangsung, serta wawancara dengan beberapa dosen lainnya yang ada di Prodi. Pend. Seni Pertunjukan.

Program Studi Pendidikan Seni Pertunjukan FKIP Untan, merupakan Prodi yang meluluskan lulusan yag siap menceraskan generasi penerus melalui bidang seni. Prodi Pendidikan Seni diadakan dalam rangka menyiapkan manusia yang mempunyai dedikasi tinggi membelajaran seni kepada para peserta didik untuk memiliki pengalaman ekspresi, kreasi dan apresiasi. Dalam Pembelajarannya, mata kuliah yang diajarkan bukan hanya fokus ke teori saja, namun juga praktik, yang tentunya pembelajarannya membutuhkan sarana dan prasarana yang memadai. Selain itu Pembelajaran daring banyak untuk mengubah gaya mengajar konvensional yang secara tidak langsung akan berdampak pada profesionalitas kerja.Peningkatan peran dan keaktifan mahasiswa dalam penggunaan berbagai media dan teknologi demi suksesnya perkuliahan daring sangatlah dipengaruhi oleh persepsi masing-masingmahasiswa.

Persepsi merupakan sebuah proses mengenal objek yang terjadi melalui bantuan alat indera manusia. Persepsi yang muncul dari dalam individu ini kemudian menggerakkan masing-masing individu mahasiswa untuk dapat mengatur dan mengelola dirinya dalam kegiatan perkuliahan secara daring. Mahasiswa perlu memiliki keterampilan mengenai cara belajar, proses berfikir, hingga memotivasi diri untuk mencapai tujuan belajar pada setiap mata kuliah (MK). Sehingga dilihat dari kebutuhan ini bahwa pembelajaran daring diasumsian bahwa pembelajaran daring akan menimbulkan banyak presepsi bagi mahasiswa baik positif maupun negatif yang dipengarui oleh banyak faktor.

Berdasarkan latar belakang tersebut peneliti sebagai dosen di Prodi Pendidikan Seni Pertunjukan merasa perlu maenganalisi dan mendeskripsikan data mengenai persepsi mahasiswa musik terhadap pembelajaran daring di Prodi Pend. Seni Pertunjukan FKIP Untan serta apasaja faktor penghambat dan pendukungnya. Rumusan masalah yang dimunculkan dalam penelitian ini adalah "Bagaimana presepsi mahasiswa musik dan tari terhadap pembelajaran daring di Prodi Pendidikan Seni Pertunjukan FKIP Untan serta Apa yang menjadi alasan mahasiswa terhadap terlaksananya pembelajaran daring di Prodi Pendidikan Seni Pertunjukan FKIP Untan". Adapun tujuan penelitian ini adalah untuk mengetahui presepsi mahasiswa musik terhadap pemelajran daring di Prodi Pend. Seni Pertunjukkan FKIP Untan serta mendeskripsikan alasan mahasiswa terhadap terlaksananya dan faktor penghambat dan pendukung pembelajaran daring bagi mahasiswa musik di Prodi Pendidikan Seni Pertunjukan FKIP Untan 
Kontribusi penelitian ini terhadap ilmu pengetahuan dapat di bagi dalam kontribusi teoritis dan praktis. Secara teoritis penelitian ini, diharapkan dapat dijadikan sebagai sumber refrensi bagi pihak universitas, khususnya bagi Program Studi Pendidikan Seni Pertunjukan dalam rangka memberikan pelayanankepada mahasiswa, serta mampu merancang strategi yang sesuai dengan kondisi pada saat melaksanakan kegiatan pembelajaran khususnya dalam bidang seni musik pada masa Covid 19. Secara praktis penelitian ini diharapkan dapat dijadikan sebagai sebagai bahan pertimbangan dalam membenahi kekurangan serta mempertahankan atau meningkatkan kelebihan- kelebihan yang ada dalam rangka meningkatkan kualitas proses pelaksanaan pembelajaran pada masa daring di Prodi Seni Tari dan Musik di Universitas Tanjungpura.

\section{METODE PENELITIAN}

Metode penelitian yang digunakan dalam penelitian ini adalah kualitatif deskripstif. Penelitian deskriptif kualititatif dipilih dalam penelitian ini dengan alasan bahwa peneliti ingin memaparkan kondisi nyata yang terjadi terkait presepsi mahasiswa terhadap pembelajaran daring di Prodi Pendidikan Seni Pertunjukan.

Adapun subjek penelitian dalam penelitian ini adalah mahasiswa Prodi Pendidikan Seni Pertunjukan di Kota Pontianak. Adapun mahasiswa tersebut berlatar mahasiswa tari dna musik. Lokasi Penelitian adalah Prodi Pendidikan Seni Pertunjukan Untan, sebagai satu satunya Prodi yang mencetak guru seni budaya. Pemilihan lokasi ini antara lain ketertarikan penelti untu mengetahui persepsi mahasiswa Prodi Seni terkait pembelajaran daring. Ketertarikan ini didasari adanya kesenjangan antara kebutuhan pembelajaran Seni yang dalam perkuliahannya menurut peneliti harus di adakan secara tatap muka karena banyaknya mata kuliah yang bersifat praktik, dengan kondisi untuk yang terjadi pada masa covid di mana harus berlajar secara daring dari rumah.

Teknik pengumpulan data yang digunakan dalam penelitian ini disesuaikan dengan data yang dikumpulkan yaitu: Observasi dan Wawancara, serta studi dokumentasi. Adapun wawancara yang dilakukan peneliti adalah wawancara langsung dan tidak langsung yaitu dengan membagikan angket kepada mahasiswa Prodi Seni Pertunjukan yaitu mahasiswa tari dan mahasiswa musik, dan pihak lain terkait penunjang data. Wawancara ini dilakukan dengan tujuan untuk mendapatkan data tentang presepsi mahasiswa terhadap pembelajaran daring yang dilaksanakan Prodi Seni Pertunjukan Untan dan faktor penghambat dan pendukung lainnya yang menunjang penelitian. Kedua dokumentasi penelitian ini berusaha menelaah dokumen- dokumen yang ada di tempat penelitian, yang meliputi dokumen kurikulum dan dokumen-dokumen lain yang relevan untuk penelitian ini, dan seperti perangkat pembelajaran dan dokumen- dokumen lain yang dapat mendukung dalam penelitian ini. Ketiga, Observasi yang dilakukan berupa observasi langsung. Observasi ini dilakukan peneliti yaitu observasi awal dan observasi saat penelitian. Observasi awal dilakukan peneliti pada tanggal bulan April 2021, kemudian observasi lanjutan dari bulan juli - September 2021. Observasi ini bertujuan untuk mengamati pembelajaran daring di Prodi Pendidikan Seni Pertunjukan. 
Tahap selanjutnya dalam penelitian ini adalah dengan melakukan pengecekan keabsahan data. Pengecekan keabsahan data dalam penelitian ini dilakukan dengan tahap perpanjang pengamatan dan triangulasi. Analisis data yang digunakan dalam penelitian ini adalah menurut Miles dan Hubermant. Menurut Miles dan Huberman dalam Sugiyono (2008:246), dengan prosedur sebagai berikut: (1) reduksi data, (2) penyajian data, dan (3) verifikasi. Proses reduksi data, data penelitian yang telah didapatkan dipilah-pilah sesuai dengan fokus masalah dari hasil pengumpulan data kemudian mengelompokkannya menjadi beberapa bagian. Seteah mengorganisisr, peneliti melakukan penyajian data. Penyajian Data berupa penceritaan kronologis yang merupakan penyederhanaan dari informasi yang banyak jumlahnya ke dalam kesatuan bentuk yang disederhanakan. Setelah penyajian data, peneliti melakukan verifikasi. Proses Verifikasi merupakan langkah terakhir dimana data yang sudah disajikan kemudian dicek kebenarannya, yang pada akhirnya dapat menjawab permasalahan penelitian yang telah dirumuskan sebelumya.

\section{HASIL PENELITIAN DAN PEMBAHASAN Profil Pendidikan Seni Pertunjukan}

Penelitian ini mengambil lokasi di Prodi Pendidikan Seni Pertujukan. Secara umum profil Prodi Pendidikan Seni Pertunjukan yang menjadi lokasi penelitian adalah Prodi yang bernaung pada Fakultas Keguuan dan Ilmu Pendidikan (FKIP) Universitas Tanjungpura yang sudah berdiri kurang lebih 13 tahun berjalan, dan sudah terakreditasi.

Prodi Pendidikan Seni Pertunjukan merupakan salah satu program studi di Kalimantan Barat yang menghasilkan lulusan yang berkompeten dalam bidang seni dan pendidik seni. Kurikulum yang dilaksnakan oleh Prodi Pendidikan Seni Pertunjukan merupakan kurikulum yang berbasis kompetensi. Kurikulum yang disusun tentunya sejalan dengan visi dan misi dari Prodi Pendidikan Seni Pertunjukan. Dimana visi Program Studi Pendidikan Seni Pertunjukan adalah menjadikan Prodi pendidikan Snei pertunjukan sebagai institusi yang menghasilkan sarjana pendidikan seni dengan keahlian dan profesionalitas dalam menghadapi tantangan lapangan kerja, khususnya di bidang Seni Tari dan Musik serta memiliki kompetensi pendagogik, kepribadian, profesional dan sosial sehingga mampu bersaing secara regional, nasional, dan internasional.

Kompetensi utama lulusan dalam kurikulum Program Studi pendidikan Seni Tari dan Musik juga sejalan dengan misi Program Studi Pendidikan Seni Tari dan Musik yakni Menyelenggarakan program sarjana pendidikan seni tari dan musik yang berkualitas, Menghasilkan lulusan yang berkompetensi dalam pedagogik, kepribadian, profesional dan sosial serta mampu bersaing secara regional dan nasional, Mengembangkan dan mengaplikasikan berbagai disiplin ilmu pendidikan seni serta keterampilan yang diperlukan sesuai dengan kebutuhan di lapangan dalam dunia pendidikan seni dan Meningkatkan kolaborasi bersama pemangku kepentingan (stakeholder) dalam mempersiapkan, melaksanakan, dan menghasilkan sumber daya yang mumpuni

Berdasarkan Visi misi tersebut maka mata kuliah yang tercantum dalam kurikulum tentunya disusun dengan mata kuliah yang bidang seni baik praktek 
maupun teori, dan juga mata kuliah yang bersifat pendagogik. Sehingga harapannya menghasilkan lulusan yang berkompeten baik dalam bidang praktisi seni dan pendidik seni yang memiliki sikap baik, intelektual dan terampil.

\section{Presepsi Mahasiswa Terhadap Pembelajaran daring di Prodi Pendidikan Seni Pertunjukan}

Penelitian ini dilaksanakan di Prodi Pendidikan Seni Pertunjukan Untan Pontianak. Jumlah responden 240 mahasiswa terdiri dari 120 mahasiswa Seni Musik dan 120 mahasiswa Seni Tari semester 3, 5 dan 7. Penyebaran angket terbuka secara daring melalui Google Form dan ada juga yang di bagikan secara langsung. Berdasarkan data yang telah dikumpulkan secara garis besar presepsi mahasiswa untuk melaksanakan pembelajaran di Prodi Pendidikan Seni Pertunjukan adalah dilaksanakan dalam bentuk tatap muka, terliebih untuk mata kuliah yang bersifat praktik. Hal ini dikarenakan mata kuliah praktik membutuhkan arahan langsung dari dosen pengampu. Selain itu beberapa mata kuliah yang bersifat teori juga butuh pengarahan langsung. Namun dari hasil data yang dikumpulkan juga ada beberapa mahasiswa yang menginginkan pembelajaran di Prodi Pendidikan Seni Pertunjukan dilaksanakan secara daring walaupun praktik. Hal ini tidak lain untuk menghindari tersebarnya virus Covid 19.

Selanjutnya Data yang didapat dari angket menunjukan tentang persepsi mahasiswa terhadap pembelajaran daring di Prodi Seni Pertunjukan Untan berisi 70 butir pernyataan yang disusun sesuai dengan mata kuliah Seni Musik dari semester 1 sampai semester 7. Setiap responden yang mengisi angket tersebut sesuai dengan persepsi/pendapat mereka sendiri disertai alasan mengapa memilih jawaban daring ataupun tatap muka. Hasil data angket 60 mahasiswa Seni Musik dan 60 mahasiswa Seni Tari tersebut dipaparkan dalam tabel berikut.

Tabel 1: Persepsi Mahasiswa Seni Musik dalam pembelajaran Daring/Luring NO Mata Kuliah PERSEPSI MAHASISWA 


\begin{tabular}{|c|c|c|c|c|}
\hline & & Daring & $\begin{array}{l}\text { Tatap } \\
\text { Muka }\end{array}$ & $\begin{array}{l}\text { Belum } \\
\text { Mengambil } \\
\text { Mata Kuliah }\end{array}$ \\
\hline 1 & Agama & 21 & 39 & 0 \\
\hline 2 & $\begin{array}{l}\text { Dasar-dasar } \quad \text { Instrumen } \\
\text { Melayu }\end{array}$ & 0 & 60 & 0 \\
\hline 3 & Tari Melayu Kalbar Dasar & 0 & 60 & 0 \\
\hline 4 & $\begin{array}{l}\text { Perkembangan } \\
\text { Didik }\end{array}$ & 50 & 10 & 0 \\
\hline 5 & Pengantar Pendidikan & 40 & 20 & 0 \\
\hline 6 & $\begin{array}{l}\text { Pengantar Pengetahuan } \\
\text { Tari }\end{array}$ & 18 & 42 & 0 \\
\hline 7 & Teori Musik Dasar & 10 & 50 & 0 \\
\hline 8 & $\begin{array}{l}\text { Pendidikan } \\
\text { Kewarganegaraan }\end{array}$ & 55 & 5 & 0 \\
\hline 9 & Piano Dasar & 0 & 60 & 0 \\
\hline 10 & Bahasa Indonesia & 40 & 10 & 0 \\
\hline 11 & $\begin{array}{ll}\text { Dasar-dasar } & \text { Instrumen } \\
\text { Musik Dayak } & \\
\end{array}$ & 5 & 55 & 0 \\
\hline 12 & Tari dayak Kalbar Dasar & 10 & 50 & 0 \\
\hline 13 & Dasar-dasar Seni Rupa & 5 & 55 & 0 \\
\hline 14 & $\begin{array}{l}\text { Media Pmebelajaran dan } \\
\text { TIK }\end{array}$ & 60 & 0 & 0 \\
\hline 15 & Belajar dan Pembelajaran & 60 & 0 & 0 \\
\hline 16 & Bahasa Inggris & 20 & 40 & 0 \\
\hline 17 & Pendidikan Pancasila & 40 & 20 & 0 \\
\hline 18 & Profesi Kependidikan & 40 & 20 & 0 \\
\hline 19 & $\begin{array}{ll}\text { Pengenalan } & \text { Budaya } \\
\text { Sekolah (PLP1) } & \end{array}$ & 0 & 60 & 0 \\
\hline 20 & Sejarah Musik & 38 & 22 & 0 \\
\hline 21 & Teori Musik Lanjut & 5 & 55 & 0 \\
\hline 22 & Piano Dasar Lanjut & 0 & 60 & 0 \\
\hline 23 & Vokal dasar & 0 & 60 & 0 \\
\hline 24 & Solfegio Dasar & 10 & 50 & 0 \\
\hline 25 & $\begin{array}{l}\text { Dasar-dasar Instrumen } \\
\text { Tiup }\end{array}$ & 0 & 60 & 0 \\
\hline 26 & Harmoni Dasar & 0 & 60 & 0 \\
\hline 27 & Apresiasi Seni & 40 & 20 & 0 \\
\hline 28 & Dasar-dasar Seni Drama & 15 & 65 & 20 \\
\hline 29 & $\begin{array}{l}\text { Perencanaan Pembelajaran } \\
\text { Seni }\end{array}$ & 60 & 20 & 20 \\
\hline 30 & Akustik Organologi & 50 & 30 & 20 \\
\hline 31 & Piano Lanjut & 0 & 40 & 20 \\
\hline 32 & Ansambel Musik Sekolah & 0 & 40 & 20 \\
\hline
\end{tabular}




\begin{tabular}{|c|c|c|c|c|}
\hline 33 & Harmoni Lanjut & 0 & 40 & 20 \\
\hline 34 & Solfegio Lanjut & 0 & 40 & 20 \\
\hline 35 & Vokal Lanjut & 0 & 40 & 20 \\
\hline 36 & Notasi Aplikasi Komputer & 0 & 40 & 20 \\
\hline 37 & Kontrapung & 0 & 40 & 20 \\
\hline 38 & Evaluasi Pembelajaran Seni & 45 & 15 & 20 \\
\hline 39 & Statistik Terapan & 25 & 15 & 20 \\
\hline 40 & $\begin{array}{ll}\text { Manajemen } & \text { Seni } \\
\text { pertunjukan } & \end{array}$ & 55 & 5 & 20 \\
\hline 41 & Metode Penelitian & 40 & 20 & 20 \\
\hline 42 & Ilmu Bentuk Analisis & 0 & 40 & 20 \\
\hline 43 & Aransemen Musik & 0 & 40 & 20 \\
\hline 44 & $\begin{array}{l}\text { Dasar-dasar Instrumen } \\
\text { Petik }\end{array}$ & 0 & 40 & 20 \\
\hline 45 & Musik Daerah Kalbar & 0 & 40 & 20 \\
\hline 46 & Direksi & 0 & 40 & 20 \\
\hline 47 & Antropologi Seni & 15 & 5 & 40 \\
\hline 48 & Kewirausahaan Seni & 15 & 5 & 40 \\
\hline 49 & Seminar Pendidikan Seni & 20 & 10 & 40 \\
\hline 50 & Pembelajaran Mikro & 0 & 20 & 40 \\
\hline 51 & Kewirausahaan Seni & 15 & 5 & 40 \\
\hline 52 & Komposisi Musik Dasar & 0 & 50 & 40 \\
\hline 53 & $\begin{array}{l}\text { Dasar-dasar Instrumen } \\
\text { Petik }\end{array}$ & 0 & 40 & 40 \\
\hline 54 & $\begin{array}{l}\text { Dasar-dasar Instrumen } \\
\text { Gesek }\end{array}$ & 0 & 40 & 40 \\
\hline 55 & Paduan Suara & 0 & 40 & 40 \\
\hline 56 & Mata kuliah Maching Band & 0 & 40 & 40 \\
\hline 57 & $\begin{array}{l}\text { Mata kuliah Kreativitas } \\
\text { Tari }\end{array}$ & 16 & 4 & 40 \\
\hline 58 & Mata kuliah PPL & 0 & 20 & 40 \\
\hline 59 & KKN & 0 & 20 & 40 \\
\hline 60 & Komposisi Musik Lanjut & 0 & 20 & 40 \\
\hline 61 & Musik Daerah Nusantara & 0 & 20 & 40 \\
\hline 62 & Musik Dayak & 0 & 20 & 40 \\
\hline 63 & Musik Melayu & 0 & 20 & 40 \\
\hline 64 & Musik Jazz & 0 & 20 & 40 \\
\hline 65 & Musik Keroncong & 0 & 20 & 40 \\
\hline 66 & Praktek Instrumen Petik & 0 & 20 & 40 \\
\hline 67 & Praktik Instrumen Perkusi & 0 & 20 & 40 \\
\hline 68 & Praktik Instrumen Gesek & 0 & 20 & 40 \\
\hline 69 & Praktik Instrumen tiup & 0 & 20 & 40 \\
\hline 70 & Skripsi & 2 & 6 & 52 \\
\hline
\end{tabular}

Tabel 2: Persepsi Mahasiswa Seni Tari dalam pembelajaran Daring/Luring 


\begin{tabular}{|c|c|c|c|c|}
\hline \multirow[b]{2}{*}{ No } & \multirow[b]{2}{*}{ Mata Kuliah } & \multicolumn{3}{|c|}{ PERSEPSI MAHASISWA } \\
\hline & & Daring & $\begin{array}{l}\text { Tatap } \\
\text { Muka }\end{array}$ & $\begin{array}{l}\text { Belum } \\
\text { Mengambil } \\
\text { Mata Kuliah }\end{array}$ \\
\hline 1 & Agama & 25 & 35 & 0 \\
\hline 2 & $\begin{array}{l}\text { Dasar-dasar Instrumen } \\
\text { Melayu }\end{array}$ & 0 & 60 & 0 \\
\hline 3 & Tari Melayu Kalbar Dasar & 0 & 60 & 0 \\
\hline 4 & $\begin{array}{l}\text { Perkembangan } \quad \text { Peserta } \\
\text { Didik }\end{array}$ & 55 & 5 & 0 \\
\hline 5 & Pengantara Pendidikan & 52 & 8 & 0 \\
\hline 6 & Pengantar Pengetahuan Tari & 40 & 20 & 0 \\
\hline 7 & Teori Musik Dasar & 30 & 30 & 0 \\
\hline 8 & $\begin{array}{l}\text { Pendidikan } \\
\text { Kewarganegaraan }\end{array}$ & 45 & 15 & 0 \\
\hline 9 & Piano Dasar & 0 & 60 & 0 \\
\hline 10 & Bahasa Indonesia & 50 & 10 & 0 \\
\hline 11 & $\begin{array}{ll}\text { Dasar-dasar } & \text { Instrumen } \\
\text { Musik Dayak } & \end{array}$ & 0 & 60 & 0 \\
\hline 12 & Tari dayak Kalbar Dasar & 0 & 60 & 0 \\
\hline 13 & Dasar-dasar Seni Rupa & 5 & 55 & 0 \\
\hline 14 & $\begin{array}{l}\text { Media Pembelajaran dan } \\
\text { TIK }\end{array}$ & 60 & 0 & 0 \\
\hline 15 & Belajar dan Pembelajaran & 60 & 0 & 0 \\
\hline 16 & Bahasa Inggris & 10 & 50 & 0 \\
\hline 17 & Pendidikan Pancasila & 40 & 20 & 0 \\
\hline 18 & Profesi Kependidikan & 52 & 8 & 0 \\
\hline 19 & $\begin{array}{l}\text { Pengenalan Budaya Sekolah } \\
\text { (PLP1 }\end{array}$ & 0 & 60 & 0 \\
\hline 20 & Tari Sumatra & 0 & 60 & 0 \\
\hline $21^{\prime}$ & Teknik Tari Tradisi & 0 & 60 & 0 \\
\hline 22 & $\begin{array}{l}\text { Tari dayak Kalbar Dasar } \\
\text { lanjut }\end{array}$ & 0 & 60 & 0 \\
\hline 23 & Tari Pendidikan Dasar & 0 & 60 & 0 \\
\hline 24 & Tata Rias & 0 & 60 & 0 \\
\hline 25 & Tata Busana & 0 & 60 & 0 \\
\hline 26 & Olah Tubuh & 0 & 60 & 0 \\
\hline 27 & Dasar-dasar Seni Drama & 5 & 35 & 20 \\
\hline 28 & $\begin{array}{l}\text { Perencanaan Pembelajarn } \\
\text { Seni }\end{array}$ & 30 & 10 & 20 \\
\hline 29 & Telaah Kurikulum & 45 & 5 & 20 \\
\hline 30 & Tari Sunda & 0 & 40 & 20 \\
\hline 31 & Tari pendidikan lanjut & 0 & 40 & 20 \\
\hline 32 & Notasi tari Dasar & 10 & 30 & 20 \\
\hline
\end{tabular}




\begin{tabular}{|c|c|c|c|c|}
\hline 33 & Teknik Tari Modern & 0 & 40 & 20 \\
\hline 34 & Rias Karakter & 0 & 40 & 20 \\
\hline 35 & Busana Kreasi & 0 & 40 & 20 \\
\hline 36 & $\begin{array}{l}\text { Tari melayu Kalbar Dasar } \\
\text { lanjut }\end{array}$ & 0 & 40 & 20 \\
\hline 37 & Evaluasi Pembelajaran Seni & 30 & 10 & 20 \\
\hline 38 & Statistik Terapan & 12 & 28 & 20 \\
\hline 39 & $\begin{array}{ll}\text { Manajemen } & \text { Seni } \\
\text { Pertunjukan } & \\
\end{array}$ & 30 & 10 & 20 \\
\hline 40 & Metode penelitian & 30 & 10 & 20 \\
\hline 41 & Tari Bali & 0 & 40 & 20 \\
\hline 42 & Notasi tari Lanjut & 0 & 40 & 20 \\
\hline 43 & Komposisi tari dasar & 0 & 40 & 20 \\
\hline 44 & Tari Mancanegara & 0 & 40 & 20 \\
\hline 45 & Kreativitas Musik & 20 & 20 & 20 \\
\hline 46 & Antropologi Seni & 16 & 4 & 40 \\
\hline 47 & Kewirausahaan Seni & 15 & 5 & 40 \\
\hline 48 & Seminar Pendidikan Seni & 14 & 6 & 40 \\
\hline 49 & Pembelajaran Mikro & 0 & 20 & 40 \\
\hline 50 & Analisis Gerak dan Karakter & 0 & 20 & 40 \\
\hline 51 & Komposisi tari lanjut & 0 & 20 & 40 \\
\hline 52 & Sejarah Tari & 15 & 5 & 40 \\
\hline 53 & Filsafat Seni & 20 & 10 & 40 \\
\hline 54 & Tari Jawa & 0 & 20 & 40 \\
\hline 55 & PLP 2/PPL 2 & 0 & 20 & 40 \\
\hline 56 & KKN & 0 & 20 & 40 \\
\hline 57 & Komposisi Tari Anak & 0 & 20 & 40 \\
\hline 58 & Dramatari & 0 & 20 & 40 \\
\hline 59 & Tari dayak Kalbar Lanjut & 0 & 20 & 40 \\
\hline 60 & Tari Melayu Kalbar Lanjut & 0 & 20 & 40 \\
\hline 61 & Etnokoreologi & 5 & 15 & 40 \\
\hline 62 & Kritik Tari & 12 & 8 & 40 \\
\hline 63 & Skripsi & 2 & 8 & 50 \\
\hline
\end{tabular}


Berdasarkan data di atas dapat dilihat bahwa sebagian besar mata kuliah praktik seperti Tari Melayu Kalbar Dasar, Piano, Vokal, Gitar, Gesek, Instrumen Tiup Musik Melayu, Musik Dayak, Musik Keroncong, Maching Band, Dramatari, Tari dayak, tari Jawa, Tari Mancanega, Rias Karakter, Busana Kreasi, Micro teaching dan mata kuliah praktik lainnya sangat diharapkan oleh mahasiswa dari Seni tari dan Musik perkuliahan dilaksanakan secara tatap muka. Hal ini didasari dengan alasan mahasiswa bahwa mata kuliah praktik lebih efektif jika dilaksanakan secara tatap muka. .Hal ini terkadang mata kuliah praktik khususnya musik dan tari memerlukan alat musik atau properti tari yang tidak di miliki oleh mahasiswa atau bahkan sulit di adakan oleh mahasiswa itu sendiri karena harga alat atau properti tersebut mahal. Sehingga hasil belajar kurang efektif. Selain itu perkuliahan tatap muka di piliih mahasiwa karena mahasiswa mendapatkan arahan secara langsung dari dosen. Dosen dapat langsung memberikan contoh yang benar dan memperbaiki apabila ada yang salah sehingga pembelajaran dapat mudah dimengerti oleh mahasiswa. Interaksi dalam perkuliahan juga terlaksana mahasiswa yang belum mengerti materi dapat langsung menanyakan ke dosen atau teman lain yang lebih paham. Sehinngga tujuan perkuliahan pun tercapai. Dengan kata lain, semakin banyak rencana atau tujuan perkuliahan yang berhasil dicapai maka suatu kegiatan dianggap semakin efektif.

Selanjutnya alasan mahasiswa memilih perkuliahan secara tatap muka untuk mata kuliah praktik dan beberapa mata kuliah teori yaitu karena perkuliahan secara tatap muka membuat mahaiswa lebih fokus belajar memperhatikan materi yang diajarkan oleh dosen. Kendala jika dilaksanakan di rumah terkadang terdapatya gangguan-gangguan yang terkadang tidak bisa di prediksi oleh mahasiswa seperti sinyal dan perangkat eror, bahkan terkadang panggilan dari orang di rumah membuat mahasiswa belajar tidak fokus.

Alasan lain yang membuat mahasiswa lebih memilih mata kuliah praktik dilaksanakan secara tatap muka yaitu karena dengan perkuliahan tatap muka mahasiswa dapat mengejar ketinggalan materi. Bagi mahasiwa yang sering mengalami kendala pada saat perkuliahan daring, perkuliahan tatap muka adalah salah satu cara untuk mengejar materi yang pernah diberikan dosen secara daring. Selanjutanya alasan lain mahasiswa leih memilih perkuliahan tatap muka yaitu terjalinnya hubungan emosioanl yang baik dengan dosen dan teman mahasiswa lainnya. Perkuliahan tatap muka membuat mahsiswa dapat beriteraksi dengan mahasiswa lainnya. Saat istirahat mahasiswa dapat bersenda gurau baik dengan dosen maupun dengan teman lainnya, yang pada saat pembelajaran daring terkadang tidak bisa dilakukan karena kendala sinyal atau waktu perkuliahan yang terbatas.

Di sisi lain pelaksnaaan pembelajaran untuk mata kuliah yang bersifat teoritis menurut mahasiswa pelaksanaannya bisa secara daring. Hal ini disampaikan oleh mahasiswa dengan alasan untuk mencegah penularan covid. Kemudian materi yang bersifat teoritis juga bisa di sampaikan secara daring, tentunya dengan memanfaatkan media yang ada, dna memuat media pembelajaran semenarik mungkin. Namun walaupun begitu mahasiswa tetap berharap bahwa perkuliahan yang bersifat teoritis juga dapat dilaksanakan secara tatap muka. Hal ini didasari karena terkadang saat penjelasan materi secara daring oleh dosen, mahasiswa mengalami kesulitan sinyal bahkan terkadang perangkat seperti HP atau Laptop untuk melaksanakan perkuliahan mengalami kerusakan mendadak karena seringnya di pakai dalam sehari. Sehingga terkadang pembelajaran daring walaupun teori dirasa kurang efektif. 
AKSARA: Jurnal Ilmu Pendidikan Nonformal

P-ISSN 2407-8018 E-ISSN 2721-7310 DOI prefix 10.37905

Volume 08, (1), January 2022

http://ejurnal.pps.ung.ac.id/index.php/Aksara

\section{Faktor-faktor pendukung dan penghambat pembelajaran daring di Prodi Pendidikan Seni Pertunjukan}

Penyebaran covid 19 menyebabkan pembelajaran daring yang dilaksanakan dari rumah dengan tujuan untuk mencegah penyebaran Covid 19, tidak terkecuali dengan pelaksnaan pembelajaran di Prodi Pendidikan Seni Pertunjukan. Pada awal masa pandemi covid 19 sampai dengan sekarang pembelajaran daring masih dilakukan oleh Prodi Pendidikan Seni Pertunjukan. Adapun dalam pelaksankaan secara daring ini tentunya memiliki faktor pendukung dan penghambat terlaksananya pembelajaran daring.

Berdasarkan hasil penelitian pada Prodi Pendidikan Seni Pertunjukan faktor pendukung pembelajaran daring adalah pertama, pelaksanakan pembelajaran daring disetujui oleh pihak kampus sehingga pembelajaran dapat dilaksnakan di dari rumah atau dari mana saja, sehingga memudahkan mahasiswa ataupun dosen untuk melaksanakan pembelajaran tanpa harus ke kampus. Kedua, mahasiswa untuk pembelajran yang bersifat teori, perangkat yang dibutuhkan dalam pembelajaran daring tidak banyak, yaitu dapat berupa HP atau laptop. Sehingga bagi yang mempunyai perangkat tersebut selain digunakan untuk melaksanakan pembelajaran dapat juga digunakan untuk mencari dan mengakses materi belajar dari berbagai sumber digital. Selalin itu pembelajaran daring memberikan pengetahuan baru kepada mahasiswa terkait cara mamaksimalkan pembelajaran menggunakan perangkat digital.

Selain faktor pendukung pembelajaran daring terdapat juga faktor penghambat. Faktor penghambat tersebut antara lain keterbatasan alat atau properti yang menunjang pembelajaran, hal ini didasarkan karena karaterisktik mata kuliah seni yang lebih membutuhkan ketersediaan alat musik ataupun properti tari dalam melakasanakan perkuliahan. Hal ini di analisis oleh peneliti dengan melihat alasan alasan siswa lebih memilih pembelajaran tatap muka bagi mata kuliah praktik. Sedangkan disisi lain pembelajaran secara daring juga memiliki hambatan pada susahnya materi dipahami oleh para mahasiswa dikarenakan kendala signal ataupun kehabisan kuota sehingga untuk mengikuti pembelajaran secara seksama tidak dapat dilaksnakan. Faktor penghambat lainnya dalam pembelajaran daring adalah kurangnya pengawasan mahasiswa saat melaksanakan pembelajaran dan kurangnya motivasi siswa dalam mengikuti perkuliahan, hal ini dapat dirasakan peneliti sebagai dosen dan juga berdasarkan wawancara dari beberapa dosen, di mana saat pembelajaran berlangsung kurangnya respon mahasiswa dalam memberikan jawaban saat dosen bertanya. Hal ini juga sebagai dampak dari bosannya mahasiswa melaksanakan pembelajaran daring di rumah.

\section{KESIMPULAN}

Dari hasil penelitian yang sudah peneliti lakukan, maka peneliti mengambil kesimpulan bahwa hampir keseluruhan mahasiswa baik Seni Musik maupun Seni Tari berpendapat bahwa mata kuliah praktek sebaiknya dilaksanakan secara tatap muka dengan alasan bahwa masih tergantung dengan properti atau peralatan yang ada di kampus dan pembelajaran tatap mata kuliah praktek akan lebih mudah dipahami terutama pada teknik memainkan alat musik bagi mahasiswa Seni Musik dan juga teknik gerak bagi mahasiswa Seni Tari. Sedangkan mata kuliah teori mahasiswa cenderung memilih daring walaupun ada mata kuliah tertenmtu yang sebenarnya mata kuliah teori 
tetapi mahasiswa memilih dilaksanakan secara tatap muka, contohnya: Teori Musik , Notasi Tari.

Dalam pembelajaran daring ada beberapa faktor penghambat yang membuat mahasiswa kesulitan melaksanakannya terutama masalah kuota, kendala jaringan internet. Selain itu tidak tersedinya media yang menunjang pada pembelajaran seni yang bersifat praktik, membuat mahasiswa tidak dapat melaksanakan pembelajaran dari rumah seutuhnya. Adapun faktor penunjang pembelajaran daring adalah pembelajaran masih tetap bisa berlangsung walaupun di masa pandemic covid19, sehingga terhindar atau memutus mata rantai penularan covid 19.

\section{SARAN}

1. Perlunya melaksanakan pembelajaran secara tatap muka dengan aturan yang ketat dan menaati protokol kesehataan untuk mata kuliah yang bersifat praktik.

2. Peran pemerintah untuk dapat memberikan bantuan kuota gratis dan perluasan jaringan internet sehingga mahasiswa dimanapun berada bisa mengakses internet.

3. Bagi dosen untuk lebih kreatif dalam memberikan materi daring terutama pada pembuatan video pembelajaran sehingga mahasiswa tertarik mengulang video apabila ada materi yang belum mengerti

\section{DAFTAR PUSTAKA}

Asrori. (2020). Psikologi Pendidikan. Jawa Tengah: CV Pena Persada.

Efendi, Albert. (2020). Konsep Pembelajaran Daring Berbasis Pendekatan Ilmiah. Jawa Tengah: SarnuUntung.

Hilmi Zhafira, Nabila. (2020). "Persepsi Mahasiswa Terhadap Pembelajaran Daring Sebagai Sarana Pembelajaran Selama Masa Karantina Covid-19”. Jurnal Bisnis dan Kajian Strategi Manajemen. Vol.4.No.1.

Liliweri, Alo. (1994). Persepsi Teoritis. Bandung: Cipta Adityta Bakti.

Nizam. 2020. Buku Panduan Penyelenggaraan Semester Gasal 2020/2021 Perguruan Tinggi. Jakarta: Direktorat Jenderal Pendidikan Tinggi Kemdikbud RI.

Ruswandi. (2017). Psikologi Pendidikan. Bandung: Cipta Pesona Sejahtera.

Sugiyono. (2008). Metode Penelitian Kualitatif dan R\&D. Bandung. Alfabeta 